\title{
A Comparison of Ground-Based Air-Blast Sprayer and Aircraft Application of Fungicides to Manage Scab in Tall Pecan Trees
}

\author{
Clive H. Bock ${ }^{\dagger}$ and Michael W. Hotchkiss
}

USDA-ARS-SEFTNRL, Byron, GA 31008

\begin{abstract}
Pecan scab (caused by Venturia effusa) is a destructive disease of pecan in the southeastern United States. Susceptible cultivars must be sprayed with fungicide every 10 to 21 days to ensure yield and kernel quality. Fungicide is most often applied using large orchard air-blast sprayers. Pecan trees grow tall, and air-blast sprays result in a gradient in spray deposition and consequently of scab. Aerial fungicide application is also practiced. Disease distribution and spray deposition of the two methods have not been compared but will provide information aiding decisions on spray application methods. We compared air-blast, aerial, and air-blast + aerial applications for efficacy controlling scab at five heights in the can-

linear relationship between scab severity and height in aerially treated trees. Air-blast + aerial treatments resulted in low severity of scab at all heights. Spray deposition on water-sensitive cards indicated a declining gradient with height using an air-blast sprayer, whereas aerial applications resulted in a low deposition at all sample heights. Air-blast sprays tended to result in less good control at heights $>12.5 \mathrm{~m}$, and aerially treated trees at $\leq 7.5 \mathrm{~m}$. The results provide insight into the efficacy and advantages of these methods for applying fungicide to control scab in tall pecan trees; further research is needed to better understand the impact of frequency and timing of these two methods.
\end{abstract} opy of $25-\mathrm{m}$ cultivar Schley pecan trees. There was a negative relationship between scab severity and height in control trees, a positive linear relationship with height in air-blast treated trees, and a generally negative
Keywords: fungicides, disease management, aerial application, spray deposition, disease severity, tree crops, yield loss
Pecan scab (caused by Venturia effusa [G. Winter] Rossman \& W.C. Allen [syn. Fusicladium effusum \{G. Winter\}, Rossman et al. 2016]) is the most important disease of pecan in the southeastern United States and in some other areas of the world (Bock 2013). The disease causes yield loss, both through reduced fruit and kernel size and quality (Gottwald and Bertrand 1983; Stevenson and Bertrand 2001) and through drop of severely infected fruit (Hunter 1983). The pathogen relies on wind and rain splash for dispersal of asexually produced conidia (Gottwald and Bertrand 1982), and these infect foliage, shoots, and fruit in the presence of adequate surface wetness and temperature (Gottwald 1985; Turechek and Stevenson 1998). The asexual cycle can be completed in as little as 7 to 10 days. The sexual stage has only just been identified (Charlton et al. 2019), but its role in the epidemiology of the disease is entirely unknown. Epidemics can occur regularly under the warm, wet conditions typical of the southeastern United States in summer (Sparks et al. 2009). Disease occurs throughout the canopy, although severity can vary with height; the most severe scab is generally observed lower in the

${ }^{\dagger}$ Corresponding author: C. H. Bock; clive.bock@usda.gov

Funding: The research was supported through the USDA-ARS CRIS project 6606-21220-011-00D and through grants from the Georgia Agricultural Commodity Commission for Pecans.

This article reports the results of research only. Mention of a trademark or proprietary product is solely for the purpose of providing specific information and does not constitute a guarantee or warranty of the product by the U.S. Department of Agriculture and does not imply its approval to the exclusion of other products that may also be suitable.

*The $\boldsymbol{e}$-Xtra logo stands for "electronic extra" and indicates there are supplementary materials published online.

The author(s) declare no conflict of interest.

Accepted for publication 23 January 2020.

This article is in the public domain and not copyrightable. It may be freely reprinted with customary crediting of the source. The American Phytopathological Society, 2020. canopy in a non-fungicide-treated tree (Bock et al. 2013, 2017a). Those spatial variations in severity also translate into varying impact on fruit size (Bock et al. 2017a, 2017b).

Historically, scab has been a challenge to manage, which is exacerbated by tree size (Demaree and Cole 1929; Bock et al. 2017c). Availability of efficacious fungicides in the 1950s and of effective equipment for application aided management of the disease (Bock et al. 2017c). Although some other crops are tall, no other orchardgrown tree crops attain the height of pecan trees. Trees in older pecan orchards may be $25 \mathrm{~m}$ in height, occasionally more, and pecan trees have been reported to have the ability to attain a height of $44 \mathrm{~m}$ (Stone 1997). Pecan fruit are produced at all heights in the tree canopy, with approximately $50 \%$ of the fruit being borne in the upper half of the canopy (Lozano-Gonzalez et al. 1992). The height of pecan trees presents issues for spray coverage whether by ground-based sprayers or aerial application (Bock et al. 2013, 2015; Reilly et al. 2007; Sumner 2004). In addition to the practical difficulties of controlling disease, the pathogen is genetically diverse (Bock et al. 2017d) and shows physiologic specialization on specific cultivars (Conner and Stevenson 2004), with a history of resistant cultivars becoming susceptible due to adaptation by the pathogen (Goff et al. 1989). Furthermore, resistance to several classes of fungicide used to manage scab has been characterized in V. effusa (Stevenson 1999; Stevenson et al. 2014), although loss of control in the field has been rare. However, imperfect spray coverage due to tree height may allow isolates with quantitative resistance to survive in areas of the canopy having less than optimal spray coverage.

Ground-based and aerial (fixed-wing or helicopter) methods to apply fungicides to control scab in pecan have been experimented with since the late 1940s (Cole 1951; Cromwell 1972; Graves 1962, 1967, 1968; Graves et al. 1972; Large 1954, 1956, 1961; Wood and Reilly 1999), but there has been little quantitative data on the efficacy of these approaches to control scab in large trees. Bertrand and Brenneman (2001) first provided quantitative data of air-blast and aerial spray applications for reducing scab, indicating limitations of aerial sprays in the lower canopy. However, that study only measured disease at two heights, 5 and $12 \mathrm{~m}$ above ground, but $12 \mathrm{~m}$ in mature pecan trees is approximately half-way up the canopy, and although the results are informative, they do not provide a canopy-wide characterization. Spray volumes applied by ground-based air-blast 
sprayers or aircraft differ by an order of magnitude. Air-blast spray is most often applied at $\sim 950$ liters/ha, whereas aerial applications are most often applied at $\sim 95$ liters/ha or less. Spray coverage by both ground-based and aerial methods has been studied at multiple heights in the canopy (Bock et al. 2015; Reilly et al. 2007; Sumner 2004), but this metric does not directly relate to reduction in scab, unless a level of spray coverage has previously been related to efficacy (which it has not). Prior research by Bock et al. $(2013,2015,2017$ a) has shown that disease is generally well-controlled by ground-based air-blast sprayers up to a height of approximately $12.5 \mathrm{~m}$ (exact height depending on a number of factors including tree structure, weather conditions, inoculum pressure, and probably sprayer type and sprayer application parameters that vary among growers). Above $12.5 \mathrm{~m}$ height, efficacy of control generally declines and disease severity can be similar to that in a nonsprayed control tree. No similar studies have been performed using aerial application or a combination of spray application methods. A better knowledge of disease distribution in mature pecan canopies in relation to fungicide application using different methods will provide a basis for more informed decision making for scab management in mature pecan orchards. Even with a better understanding of coverage and control, questions will remain regarding optimal volumes, spray timing, and frequency using these methods, perhaps in conjunction with available weather advisories developed for pecan scab (Brenneman et al. 1999; Payne and Smith 2012). In addition, different stages in tree development may benefit more from fungicide application using specific methods (or combinations of methods) for control of pecan scab.

The objectives of this study were to compare (i) disease control and distribution and (ii) spray deposition in trees receiving fungicide by ground-based or aerial application methods, to better understand the effects of these spray application methods and determine which of these methods were superior to control scab in pecan orchards.

\section{Materials and Methods}

Orchard management and experiment design. The experiments were conducted in two consecutive years (2013 and 2014) in an orchard of 75- to 80-year-old, 22- to 25-m tall pecan trees (cv. Schley) planted on a $24 \times 24 \mathrm{~m}$ spacing, and located at the USDA-ARS Southeastern Fruit and Tree Nut Research Laboratory in Byron, GA $\left(+32^{\circ} 39^{\prime} 54^{\prime \prime} \mathrm{N},+83^{\circ} 44^{\prime} 31^{\prime \prime} \mathrm{W}\right.$, elevation of $\left.\approx 156 \mathrm{~m}\right)$. Ground-based applications of fungicide were applied using a Durand-Wayland 3210A $3790 \mathrm{~L}$ orchard sprayer powered by a 325-hp engine (Durand-Wayland, LaGrange, GA) operated at $3.22 \mathrm{~km} / \mathrm{h}$ and calibrated for 940 liters/ha at 10.3 bar $\left(1.03 \times 10^{6}\right.$ pascal). The sprayer nozzles were adjusted for spraying mature pecan trees (Bock et al. 2015). Briefly, all nozzles in the manifold were fitted with a number 25 ceramic swirl plate (Spraying Systems, Wheaton, IL). Nozzle disc numbers were as follows from sprayer nozzle position 1 (lowest) to sprayer nozzle position 13 (highest) for the front and rear sprayer racks $(X=$ blank). Forward rack sprayer nozzle positions 1 to $7=$ disc number 2 , position $8=$ disc number 3 , position $9=$ disc number 4 , and positions 10 to $13=$ disc number 6 . Rear rack sprayer nozzle positions 1 and $2=X$, positions 3 to $7=\operatorname{disc}$ number 2 , position $8=$ disc number 3 , position $9=$ disc number 4 , and positions 10 to $13=$ disc number 6 . Nozzles were positioned to spray $2 / 3$ to $3 / 4$ of the fungicide suspension to the upper half of the trees, and $1 / 3$ to $1 / 4$ of the spray to the lower half of the trees (Sumner 2012). For aerial application, an Ayers Thrush fixed-wing aircraft (Thrush Aircraft, Albany, GA) fitted with 32 adjustable CP nozzles operated at 3.1 to 3.4 bar ( 3.1 to $3.4 \times 10^{5}$ pascal) calibrated to deliver 74 to 94 liters/ha was flown at $225 \mathrm{kph}$ and operated at 2 to $3 \mathrm{~m}$ above the tree canopy.

In 2013, a total of six fungicide sprays were applied for each treatment. Air-blast sprayer treatments were applied on 22 April, 7 May, 20 May, 10 June, 1 July, and 27 August and aerial applications on 26 April, 8 May, 21 May, 12 June, 2 July, and 30 August. The first three sprays were Quadris Top (azoxystrobin + difenoconazole; 1.0 liter/ ha; Syngenta, Greensboro, NC), followed by one application of AgriTin Flowable (triphenyltin hydroxide; 0.90 liter/ha; Nufarm Americas, Burr Ridge, IL), with the final two applications of Super Tin
4L (triphenyltin hydroxide; 0.90 liter/ha; United Phosphorous, King of Prussia, PA). In 2014, there were a total of five sprays applied for each treatment. In 2014, air-blast sprayer treatments were applied on 28 April, 21 May, 13 June, and 7 and 29 July, and aerial applications on 5 and 30 May, 21 June, and 11 and 31 July. The first two applications were Quilt (azoxystrobin + propiconazole; 2.00 liters/ha; Syngenta), followed by one application of AgriTin Flowable and two applications of Super Tin 4L, both as described for 2013. Otherwise, the orchard received standard management practice (Wells 2017).

There were four treatments: a nontreated control, air-blast applied fungicide, aerially applied fungicide, and a combination of air-blast and aerially (air-blast + aerially) applied fungicide. The nature of large-tree orchards often means restricted randomization is inevitable due to orchard size, number of trees, and tree distribution constraints. Thus, in this case the pecan orchard had 15 rows, and we applied fungicide by airplane to four rows of trees separated from each other by three unsprayed rows of pecan trees; individual trees in the aerially treated row were sampled for the aerially applied and air-blast + aerially applied fungicide treatments (i.e., air-blast fungicide sprays were applied to only the experiment air-blast + aerially treated trees in the aerially treated row). Pecan trees in the middle row of those rows not receiving an aerial treatment application were used as the nontreated control trees or received fungicide using only an airblast sprayer. Given treatment location restrictions, sample trees within each treatment were randomly assigned as the main plots, and height was considered as a subplot. Thus, the experiment is a split-plot design (plot $=$ treatment [individual trees receiving different fungicide treatments], split plot $=$ height). There were eight replicate trees for each treatment in both 2013 and 2014, and the sample unit (described in detail in the following section) was the sample collected at a single height in a tree. An untreated guard row of trees was left at either side of the orchard, and row-end trees were not used in the experiment (18 trees per row, although there were some missing trees).

Sampling and assessments. Whole pinnately compound leaves and fruit samples were collected in both 2013 and 2014. In 2013, leaves and a first and second sample of fruit were collected on 19 July, 3 September, and 9 October, respectively, and in 2014, on 8 July, 18 July, and 10 October, respectively. Samples were collected using a hydraulic lift (JLG Industries, McConnellsburg, PA) following vertical transects up the canopy and taking samples at $2.5-\mathrm{m}$ intervals $(5.0,7.5,10.0,12.5$, and $15.0 \mathrm{~m})$. The maximum sample height was dictated by the limits of the hydraulic lift, and specific heights were determined using an Opti-Logic Laser Rangefinder (Opti-Logic, Tullahoma, TN). Ten leaves and 10 fruit were collected arbitrarily at each sample height. The percent area infected was visually assessed by a trained and experienced rater on each leaflet of each compound leaf. Scab on fruit was assessed similarly, although pecan fruit are comprised of four valve faces, and each of the faces was assessed individually (and subsequently averaged) using a standard area diagram set to improve accuracy of pecan scab severity estimates (Yadav et al. 2013).

Spray coverage. In 2013, water-sensitive paper cards $(52 \times$ $76 \mathrm{~mm}$, Syngenta) were used to measure spray coverage (Bock et al. 2015). The cards were stapled to leaves in a manner to mimic how a pecan leaf typically hangs in the canopy at 5.0, 7.5, 10.0, 12.5 , and $15.0 \mathrm{~m}$ along a vertical transect on the row side of the tree. A set of cards was stapled to leaves both on terminals on the inner (close to the trunk) and outer (the canopy surface) canopy of the tree. Cards were thus positioned using a hydraulic lift in three replicate trees for each application method. The experiment was conducted twice per spray application method receiving an air-blast application on 23 May and 10 September 2013 or aerial application on 21 May and 30 August 2013. A zero-height sample was included in the aerial application experiment on 30 August and the air-blast application experiments on 10 September.

To characterize spray coverage patterns in the absence of tree canopy, a further set of cards was secured on platforms at different heights on strings attached to helium-filled balloons, as previously described (Bock et al. 2015). The water-sensitive cards were stapled 
to the upper surface of the platform, and a second set was stapled to the lower surface of the platform. The platform sample heights were 5.0, 10.0, 15.0, and 20.0, and $25.0 \mathrm{~m}$. The experiments were conducted once for both the air-blast and aerial spray application on 10 September and 30 August 2013, respectively. In all cases a single pass was made. Cards were allowed to dry in the canopy prior to collection. Once dry, cards were removed and scanned using a flatbed scanner prior to image analysis to determine the percentage area covered using APS Assess version 2.2 (Lamari 2002) in HSI color space and using the manual panel.

Weather conditions. Weather conditions each year (temperature, relative humidity, wind speed and direction, and rainfall) were recorded using a Campbell Scientific weather station (Campbell Scientific, Logan, UT) located at the USDA-ARS-SEFTNRL, which is part of the Georgia Automated Environmental Monitoring Network (http://www.georgiaweather.net/). Mean daily weather conditions for the period 10 April to 30 September were obtained for each year.

Data analysis. The scab severity data were analyzed by analysis of variance using a generalized linear mixed model (GLIMMIX) as a split plot with main effects of treatment and height, the interaction treatment $\times$ height, and random effects of replicate nested within treatment. For all variables, convergence criteria were met, and the Akaike information criterion values were inspected to assess model fit. Residuals, homogeneity of variance, and normality were assessed to ensure the data did not violate assumptions of the analysis. Least square means (lsmeans) were calculated for all main effects and interactions, and simple main effects (slices) calculated for the interaction terms, applying the conservative Tukey's honestly significant difference adjustment to the post hoc tests to establish differences among means $(\alpha=0.05)$. The simple effects were analyzed to more accurately determine at which level of the opposing variable there was an effect on the dependent variable and to identify where the effect of that variable was significantly different from zero. Spray coverage data from the water-sensitive spray card tests were analyzed similarly, except fixed effects were height and card position/ orientation and the interaction. Main effects and interactions were assessed for the spray card coverage data.

Linear regression analysis was performed to explore the relationships between scab severity on fruit and height (using means by height and treatment). Intercepts and slopes were inspected for deviation from " 0 " or " 1 " (using a $t$ test), respectively, and the relationships were assessed first based on the model fit ( $F$ and $P$ values of the general linear model) and second by the coefficient of determination $\left(R^{2}\right)$ and coefficient of variation (\%). All statistical analyses were performed using SAS version 9.4 (SAS Institute, Cary, NC).

\section{Results}

Weather conditions. The weather conditions in 2013 were particularly wet, with above-average precipitation in June, July, and August, during the period of nut fill (Supplementary Fig. 1). In 2014 they were drier and more typical of the long-term average. The typical total rainfall for the period 1 April to 30 September is $570.7 \mathrm{~mm}$
(1949 to 2014): in 2013 a total of 1,010.2 $\mathrm{mm}$ fell, whereas in 2014 there was a total of $557.8 \mathrm{~mm}$.

Effect of spray method on disease distribution. The GLIMMIX analysis showed that there were both main effects and interactions for most disease variables, although interactions of treatment $\times$ height predominated (Supplementary Table 1).

Summary results of analysis. Treatment $\times$ height interactions were found in the case of most variables (Supplementary Table 1) and are described in detail below. Main effects of treatment are presented (Table 1) but are not considered further, because they have limited value for interpretation. Simple effects of the interactions were subsequently analyzed to better ascertain the effects at individual levels of the opposing variables of treatment and height.

Simple effects of spray treatment. At $5 \mathrm{~m}$ height in 2013, severity on infected leaflets was not significantly different among any treatments $(F=1.2, P=0.3)$, but in 2014 there was significantly less severe scab $(F=6.6, P=0.005)$ on leaflets of trees receiving air-blast $(0.48 \%)$ or air-blast + aerial $(0.58 \%)$ spray treatments compared with the control $(1.08 \%)$. The nontreated control was not different from the aerial spray treatments $(1.18 \%)$ (as noted, severity on foliage was very low throughout the canopy in both seasons) (Table 2). At $7.5 \mathrm{~m}$ severity of scab on infected leaflets was not significantly different among any treatments in $2013(F=0.7, P=0.5)$ or 2014 $(F=0.6, P=0.6)$. The severity on leaflets at $10 \mathrm{~m}$ in 2013 was not significantly different $(F=0.3, P=0.8)$ among treatments, but in 2014 there was significantly $(F=2.6, P=0.05)$ more severe scab on leaflets of trees treated with aerial applications (1.01\%) compared with the other treatment methods or the nontreated control $(0.52$ to $0.62 \%)$. At $12.5 \mathrm{~m} \mathrm{scab}$ severity on infected leaflets was not significantly different among any treatments in $2013(F=1.1, P=0.4)$ or $2014(F=0.6, P=0.6)$. Similarly, at $15 \mathrm{~m} \mathrm{scab}$ severity on infected leaflets was not significantly different among any treatments in 2013 $(F=0.4, P=0.7)$ or $2014(F=0.9, P=0.5)$.

Scab severity on fruit at the time of the first sampling was significantly different among treatments at $5 \mathrm{~m}$ in both $2013(F=13.9, P<$ $0.0001)$ and $2014(F=8.8, P<0.0001)$ (Table 2$)$. In 2013, severity of scab was lower on all treatments (2.99 to $10.34 \%$ ) compared with the nontreated control (58.89\%). In 2014, all treatments had less severe scab compared with the nontreated control (1.98\%); in addition, the air-blast $(0.05 \%)$ and air-blast + aerial $(0.02 \%)$ treatments had less severe scab compared with the aerial treatment $(0.94 \%)$. At $7.5 \mathrm{~m}$ in both 2013 and 2014 there was a significant effect of treatment ( $F=11.3$ and $3.1, P<0.0001$ and 0.03 , respectively) on scab severity on fruit. In 2013 severity was less on all treatments (3.24 to $7.74 \%$ ) compared with the nontreated control (53.19\%). In 2014, both the air-blast $(0.07 \%)$ and air-blast + aerial $(0.11 \%)$ had less severe scab compared with the nontreated control $(1.24 \%)$, and the aerial treatment $(0.66 \%)$ was not different compared with either group. At 10 m severity of scab in 2013 was lower $(F=8.4, P<0.0001)$ on all treatments (2.34 to $13.59 \%$ ) compared with the nontreated control (48.50\%), but in 2014 there were no differences $(F=1.8, P=0.2)$ in scab severity among trees treated with the different application

Table 1. Main effects of fungicide application method on severity of scab caused by Venturia effusa on foliage and on fruit at different sampling times during the season in 2013 and 2014

\begin{tabular}{|c|c|c|c|c|c|}
\hline \multirow[b]{2}{*}{$\underline{\text { Year and variable }^{\mathrm{x}}}$} & \multicolumn{4}{|c|}{ Treatment $^{\mathrm{y}}$} & \multirow[b]{2}{*}{$F$ value $(P)^{\mathbf{z}}$} \\
\hline & Control & Air-blast & Aerial & Air-blast + aerial & \\
\hline 2013 severity per infected leaflet ( $\%$ area) & $0.18 \mathrm{a}$ & $0.12 \mathrm{a}$ & $0.18 \mathrm{a}$ & $0.07 \mathrm{a}$ & $0.5(0.7)$ \\
\hline 2014 severity per infected leaflet (\% area) & $0.74 \mathrm{a}$ & $0.60 \mathrm{a}$ & $0.92 \mathrm{a}$ & $0.65 \mathrm{a}$ & $1.9(0.2)$ \\
\hline 2013 severity per fruit (first fruit sample \% area) & $50.6 \mathrm{a}$ & $14.4 \mathrm{~b}$ & $5.2 \mathrm{~b}$ & $3.2 \mathrm{~b}$ & $10.1(0.0001)$ \\
\hline 2014 severity per fruit (first fruit sample \% area) & $1.06 \mathrm{a}$ & $0.15 \mathrm{a}$ & $0.66 \mathrm{a}$ & $0.15 \mathrm{a}$ & $2.5(0.08)$ \\
\hline 2013 severity per fruit (second fruit sample $\%$ area) & $23.0 \mathrm{a}$ & $13.6 \mathrm{ab}$ & $10.6 \mathrm{ab}$ & $4.3 \mathrm{~b}$ & $5.8(0.004)$ \\
\hline 2014 severity per fruit (second fruit sample $\%$ area) & $19.17 \mathrm{a}$ & $3.74 \mathrm{ab}$ & $7.09 \mathrm{ab}$ & $0.65 \mathrm{~b}$ & $3.9(0.02)$ \\
\hline
\end{tabular}


methods or left as nontreated controls. At $12.5 \mathrm{~m}$ severity of scab in 2013 was lower $(F=9.6, P<0.0001)$ on all treatments $(2.08$ to $11.98 \%$ ) compared with the nontreated control (49.29\%), but there was no difference in severity among the treatment methods. In contrast, in 2014 there was no difference $(F=0.6, P=0.6)$ in severity between any treatments or the nontreated control. In 2013 at the highest sample point in the canopy, $15 \mathrm{~m}$, there were similar severities of scab on the control (49.29\%) and air-blast treated trees (35.06\%), but both the aerial $(2.09 \%)$ and air-blast + aerial $(3.24 \%)$ treated trees had less severe scab $(F=8.7, P<0.0001)$. In 2014 there was no difference in severity at $15 \mathrm{~m}$ between any treatments or the control $(F=$ $0.2, P=0.9)$.

At the time of the second fruit sampling in 2013, at $5 \mathrm{~m}$ in the canopy scab severity was greatest on the nontreated control $(33.36 \%)$ compared with the severity on trees of all other treatments $(F=$ $15.4, P<0.0001)$; scab severity was different between the aerial $(13.18 \%)$ and air-blast + aerial $(3.05 \%)$ treated trees, although severity on the air-blast treated trees $(5.73 \%)$ was not different from either (Table 2). In 2014 there were differences among treatments $(F=4.2$, $P=0.006)$, with more severe scab on the nontreated control $(18.78 \%)$ compared with the air-blast treated trees $(0.75 \%)$ and air-blast + aerially treated trees $(0.24 \%)$, although the aerially treated trees $(7.96 \%)$ were not different to either, or the nontreated control. At $7.5 \mathrm{~m}$ in 2013 severity was greatest $(F=8.5, P<0.0001)$ on the nontreated control $(28.16 \%)$ compared with all other treatments $(4.02$ to $13.67 \%$ ), which were not different from each other. In 2014 trees from the nontreated control $(23.57 \%)$ and aerial treatment $(15.16 \%)$ had similar scab severity values, which were higher $(F=6.8$,
$P<0.0001)$ than on those trees receiving the air-blast $(1.91 \%)$ or air-blast + aerial treatments $(0.41 \%)$. Scab severity in 2013 at $10 \mathrm{~m}$ was higher $(F=4.2, P=0.006)$ on the nontreated control trees (22.39\%) compared with all other treatments (5.10 to $12.10 \%)$, as was the case in $2014(F=4.7, P=0.003$; control $=20.30 \%$, other treatments 0.67 to $3.45 \%$, respectively). In 2013 at $12.5 \mathrm{~m}$ scab was less severe $(F=3.3, P=0.02)$ on trees that received the airblast + aerial treatment $(4.08 \%)$ compared with the nontreated control $(16.95 \%)$ and air-blast treatment $(16.14 \%)$ but was not different from the aerial treatment $(7.47 \%)$, which did not differ from the other two treatments either. In 2014 all treatments had less severe scab $(F=$ $3.1, P=0.03 ; 0.86$ to $5.45 \%$ ) compared with the nontreated control $(18.10 \%)$ but were not different from each other. At $15 \mathrm{~m}$ in 2013, the air-blast treatment $(22.45 \%)$ had more severe scab compared with the aerial $(6.81 \%)$ and air-blast + aerial $(5.07 \%)$ treatments but was not different to severity on trees of the nontreated control (14.15\%), which was not different to the severity on the other two treatments. In 2014 , the difference was not significant $(F=2.0, P=0.1)$, although the numeric trend indicated scab severity was lower on the air-blast + aerially treated $(1.09 \%)$ trees compared with the control $(15.07 \%)$; however, scab severity in trees that received the air-blast $(8.36 \%)$ or aerial $(4.12 \%)$ treatments was not different from that in nontreated control trees or those that received the combination treatment.

Simple effects of height. In 2013, severity per infected leaflet declined $(F=3.1, P=0.02)$ overall with sample height on nontreated control trees $(0.28 \%$ at $5 \mathrm{~m}$ to $0.08 \%$ at $15 \mathrm{~m})$, as it did in 2014 $(F=3.9, P=0.004 ; 1.08 \%$ at $5 \mathrm{~m}$ and $0.58 \%$ at $15 \mathrm{~m})$ (Table 3$)$.

Table 2. Simple effects of fungicide application method on severity of scab, caused by Venturia effusa, at different sample heights above ground in tall pecan trees (cv. Schley)

\begin{tabular}{|c|c|c|c|c|c|c|}
\hline \multirow[b]{2}{*}{ Year and variablew } & \multirow[b]{2}{*}{ Treatment $^{\mathrm{x}}$} & \multicolumn{5}{|c|}{ Height (m) } \\
\hline & & 5 & 7.5 & 10 & 12.5 & 15 \\
\hline \multirow{5}{*}{$\begin{array}{l}2013 \text { severity per infected } \\
\text { leaflet (\% area) }\end{array}$} & Control & $0.28 \mathrm{a}^{\mathrm{y}}$ & $0.21 \mathrm{a}$ & $0.15 \mathrm{a}$ & $0.18 \mathrm{a}$ & $0.08 \mathrm{a}$ \\
\hline & Air-blast & $0.14 \mathrm{a}$ & $0.14 \mathrm{a}$ & $0.07 \mathrm{a}$ & $0.25 \mathrm{a}$ & $0.03 \mathrm{a}$ \\
\hline & Aerial & $0.18 \mathrm{a}$ & $0.18 \mathrm{a}$ & $0.16 \mathrm{a}$ & $0.23 \mathrm{a}$ & $0.15 \mathrm{a}$ \\
\hline & Air-blast + aerial & $0.07 \mathrm{a}$ & $0.05 \mathrm{a}$ & $0.13 \mathrm{a}$ & $0.06 \mathrm{a}$ & $0.06 \mathrm{a}$ \\
\hline & $F$ value $(P)^{\mathrm{z}}$ & $1.2(0.3)$ & $0.7(0.5)$ & $0.3(0.8)$ & $1.1(0.4)$ & $0.4(0.7)$ \\
\hline \multirow{5}{*}{$\begin{array}{l}2014 \text { severity per infected } \\
\text { leaflet (\% area) }\end{array}$} & Control & $1.08 \mathrm{a}$ & $0.75 \mathrm{a}$ & $0.62 \mathrm{~b}$ & $0.66 \mathrm{a}$ & $0.58 \mathrm{a}$ \\
\hline & Air-blast & $0.48 \mathrm{~b}$ & $0.61 \mathrm{a}$ & $0.60 \mathrm{~b}$ & $0.70 \mathrm{a}$ & $0.61 \mathrm{a}$ \\
\hline & Aerial & $1.18 \mathrm{a}$ & $0.87 \mathrm{a}$ & $1.01 \mathrm{a}$ & $0.74 \mathrm{a}$ & $0.81 \mathrm{a}$ \\
\hline & Air-blast + aerial & $0.58 \mathrm{~b}$ & $0.76 \mathrm{a}$ & $0.52 \mathrm{~b}$ & $0.90 \mathrm{a}$ & $0.51 \mathrm{a}$ \\
\hline & $F$ value $(P)$ & $6.6(0.0002)$ & $0.6(0.6)$ & $2.6(0.05)$ & $0.6(0.6)$ & $0.9(0.5)$ \\
\hline \multirow{5}{*}{$\begin{array}{l}2013 \text { severity per fruit } \\
\text { (first fruit sample \% area) }\end{array}$} & Control & $58.89 \mathrm{a}$ & $53.19 \mathrm{a}$ & $48.50 \mathrm{a}$ & $49.29 \mathrm{a}$ & $43.16 \mathrm{a}$ \\
\hline & Air-blast & $3.45 \mathrm{~b}$ & $7.74 \mathrm{~b}$ & $13.59 \mathrm{~b}$ & $11.98 \mathrm{~b}$ & $35.06 \mathrm{a}$ \\
\hline & Aerial & $10.34 \mathrm{~b}$ & $3.24 \mathrm{~b}$ & $8.22 \mathrm{~b}$ & $2.08 \mathrm{~b}$ & $2.09 \mathrm{~b}$ \\
\hline & Air-blast + aerial & $2.99 \mathrm{~b}$ & $4.22 \mathrm{~b}$ & $2.34 \mathrm{~b}$ & $3.20 \mathrm{~b}$ & $3.24 \mathrm{~b}$ \\
\hline & $F$ value $(P)$ & $13.9(<0.0001)$ & $11.3(<0.0001)$ & $8.4(<0.0001)$ & $9.6(<0.0001)$ & $8.7(<0.0001)$ \\
\hline \multirow{5}{*}{$\begin{array}{l}2014 \text { severity per fruit } \\
\text { (first fruit sample \% area) }\end{array}$} & Control & $1.98 \mathrm{a}$ & $1.24 \mathrm{a}$ & $0.75 \mathrm{a}$ & $0.77 \mathrm{a}$ & $0.54 \mathrm{a}$ \\
\hline & Air-blast & $0.05 \mathrm{c}$ & $0.07 \mathrm{~b}$ & $0.08 \mathrm{a}$ & $0.33 \mathrm{a}$ & $0.19 \mathrm{a}$ \\
\hline & Aerial & $0.94 \mathrm{~b}$ & $0.66 \mathrm{ab}$ & $0.80 \mathrm{a}$ & $0.47 \mathrm{a}$ & $0.45 \mathrm{a}$ \\
\hline & Air-blast + aerial & $0.02 \mathrm{c}$ & $0.11 \mathrm{~b}$ & $0.03 \mathrm{a}$ & $0.21 \mathrm{a}$ & $0.39 \mathrm{a}$ \\
\hline & $F$ value $(P)$ & $8.8(<0.0001)$ & $3.1(0.03)$ & $1.8(0.2)$ & $0.6(0.6)$ & $0.2(0.9)$ \\
\hline \multirow{5}{*}{$\begin{array}{l}2013 \text { severity per fruit } \\
\text { (second fruit sample \% area) }\end{array}$} & Control & $33.36 \mathrm{a}$ & $28.16 \mathrm{a}$ & $22.39 \mathrm{a}$ & $16.95 \mathrm{a}$ & $14.15 \mathrm{ab}$ \\
\hline & Air-blast & $5.73 \mathrm{bc}$ & $11.32 \mathrm{~b}$ & $12.10 \mathrm{~b}$ & $16.14 \mathrm{a}$ & $22.45 \mathrm{a}$ \\
\hline & Aerial & $13.18 \mathrm{~b}$ & $13.67 \mathrm{~b}$ & $11.62 \mathrm{~b}$ & $7.47 \mathrm{ab}$ & $6.81 \mathrm{~b}$ \\
\hline & Air-blast + aerial & $3.05 \mathrm{c}$ & $4.02 \mathrm{~b}$ & $5.10 \mathrm{~b}$ & $4.08 \mathrm{~b}$ & $5.07 \mathrm{~b}$ \\
\hline & $F$ value $(P)$ & $15.4(<0.0001)$ & $8.5(<0.0001)$ & $4.2(0.006)$ & $3.3(0.02)$ & $4.8(0.003)$ \\
\hline \multirow{5}{*}{$\begin{array}{l}2014 \text { severity per fruit } \\
\text { (second fruit sample \% area) }\end{array}$} & Control & $18.78 \mathrm{a}$ & $23.57 \mathrm{a}$ & $20.30 \mathrm{a}$ & $18.10 \mathrm{a}$ & $15.07 \mathrm{a}$ \\
\hline & Air-blast & $0.75 \mathrm{~b}$ & $1.91 \mathrm{~b}$ & $2.24 \mathrm{~b}$ & $5.45 \mathrm{~b}$ & $8.36 \mathrm{ab}$ \\
\hline & Aerial & $7.96 \mathrm{ab}$ & $15.16 \mathrm{a}$ & $3.45 \mathrm{~b}$ & $4.74 \mathrm{~b}$ & $4.12 \mathrm{ab}$ \\
\hline & Air-blast + aerial & $0.24 \mathrm{~b}$ & $0.41 \mathrm{~b}$ & $0.67 \mathrm{~b}$ & $0.86 \mathrm{~b}$ & $1.09 \mathrm{~b}$ \\
\hline & $F$ value $(P)$ & $4.2(0.006)$ & $6.8(0.0001)$ & $4.7(0.003)$ & $3.1(0.03)$ & $2.0(0.1)$ \\
\hline
\end{tabular}

w In 2013, the leaf sample was collected on 19 July, and the first and second samples of fruit were collected on 3 September and 9 October, respectively. In 2014 the leaf sample was collected on 8 July, and the first and second samples of fruit were collected on 18 July and 10 October, respectively.

$\mathrm{x}$ Treatments were a nontreated control, ground-based air-blast applied fungicide (air-blast), aerially applied fungicide (aerial), and a combination of air-blast and aerially (air-blast + aerial) applied fungicide.

y If means within the column have different letters, they are significantly different $(\alpha=0.05)$.

z $P$ value indicates the probability of an $F$ value larger than the calculated value if the null hypothesis (of no treatment differences) is true. 
On air-blast treated trees in 2013, severity depended on sample height $(F=4.1,0.03)$, but it was not consistent because severity was greatest at $12.5 \mathrm{~m}(0.25 \%)$ and least at 15 and $10 \mathrm{~m}(0.03$ and $0.07 \%$, respectively). There was no effect of height in $2014(F=0.6, P=0.7)$. There was no effect of aerial treatment on scab severity on leaflets at different sample heights in $2013(F=0.5, P=0.8)$, but in 2014 there was more severe scab $(F=3.1, P=0.02)$ low in the canopy at $5 \mathrm{~m}(1.18 \%)$ compared with $15 \mathrm{~m}(0.81 \%)$. On those trees receiving the air-blast + aerial treatment there was no significant effect of sample height in $2013(F=0.5, P=0.8)$ or $2014(F=0.6, P=0.7)$.

At the time of the first fruit sampling in nontreated control trees in 2013 , scab was most severe $(F=9.7, P<0.0001)$ low in the canopy $(58.89 \%)$, with an overall decline in severity with height $(43.46 \%)$ (Table 3). There was a similar trend in $2014(F=13.5, P<$ $0.0001)$, with the most severe scab at $5 \mathrm{~m}(1.98 \%)$ compared with $15 \mathrm{~m}(0.54 \%)$. In trees receiving the air-blast treatment there was an increase $(F=36.9, P<0.0001)$ in scab severity from low in the canopy at $5 \mathrm{~m}(3.45 \%)$ to $15 \mathrm{~m}(35.06 \%)$. There was no effect of height $(F=0.6, P=0.7)$ in 2014 . For those trees receiving the aerial treatment, in 2013 there was an overall decline $(F=3.8, P=0.005)$ in scab severity from $5 \mathrm{~m}(10.34 \%)$ to $15 \mathrm{~m}(2.09 \%)$, but in 2014 there was no significant effect $(F=1.7, P=0.1)$. For trees receiving the air-blast
+ aerial treatment, there was no effect of sample height on scab severity in either $2013(F=0.1, P=1.0)$ or $2014(F=0.9, P=0.5)$.

At the time of the second fruit sampling in control trees in 2013, scab severity decreased $(F=31.6, P<0.0001)$ with increasing sample height from $5 \mathrm{~m}(33.36 \%)$ to $15 \mathrm{~m}(14.15 \%)$ (Table 3$)$. Similarly, in 2014 the nontreated control trees had more severe scab $(F=7.4$, $P<0.0001)$ low in the canopy $(18.78$ and $23.57 \%$ at 5 and $7.5 \mathrm{~m}$, respectively), with declining scab severity to $15 \mathrm{~m}(15.07 \%)$. For those trees receiving air-blast treatment in 2013, there was least severe scab $(F=18.1, P<0.0001)$ at $5 \mathrm{~m}(5.73 \%)$ and an increase in severity with sample height to $15 \mathrm{~m}(22.45 \%)$. In 2014, trees receiving the air-blast spray also had the least severe scab $(F=7.4, P<0.0001)$ at $5 \mathrm{~m}$ $(0.76 \%)$, with severity increasing with sample height to $15 \mathrm{~m}$ $(8.36 \%)$. In 2013, those trees receiving the aerial application had the most severe scab $(F=4.8, P=0.0007)$ low in the canopy at $5 \mathrm{~m}(13.18 \%)$, with a decline in severity with sample height to $15 \mathrm{~m}(6.81 \%)$. In 2014, those trees receiving the aerial treatment also had more severe scab $(F=17.8, P<0.0001)$ low in the canopy at $7.5 \mathrm{~m}(15.16 \%)$ and least severe scab at $15 \mathrm{~m}(4.12 \%)$. In 2013 and 2014 there was no difference $(F=0.4$ and $0.1, P=0.8$ and 1.0 , respectively) in scab severity at any height in trees receiving the air-blast + aerial treatment.

Table 3. Simple effects of sample height above ground on severity of scab, caused by Venturia effusa, when using different methods to apply fungicides to tall pecan trees (cv. Schley)

\begin{tabular}{|c|c|c|c|c|c|}
\hline \multirow[b]{2}{*}{ Year and variablew } & \multirow[b]{2}{*}{ Height } & \multicolumn{4}{|c|}{ Treatment $^{\mathrm{x}}$} \\
\hline & & Control & Air-blast & Aerial & Air-blast + aerial \\
\hline \multirow{6}{*}{$\begin{array}{l}2013 \text { severity per infected } \\
\text { leaflet (\% area) }\end{array}$} & 5 & $0.28 \mathrm{a}^{\mathrm{y}}$ & $0.14 \mathrm{ab}$ & $0.18 \mathrm{a}$ & $0.07 \mathrm{a}$ \\
\hline & 7.5 & $0.21 \mathrm{ab}$ & $0.14 \mathrm{ab}$ & $0.18 \mathrm{a}$ & $0.05 \mathrm{a}$ \\
\hline & 10 & $0.15 \mathrm{bc}$ & $0.07 \mathrm{~b}$ & $0.16 \mathrm{a}$ & $0.13 \mathrm{a}$ \\
\hline & 12.5 & $0.18 \mathrm{abc}$ & $0.25 \mathrm{a}$ & $0.23 \mathrm{a}$ & $0.06 \mathrm{a}$ \\
\hline & 15 & $0.08 \mathrm{c}$ & $0.03 \mathrm{~b}$ & $0.15 \mathrm{a}$ & $0.06 \mathrm{a}$ \\
\hline & $F$ value $(P)^{\mathrm{z}}$ & $3.1(0.02)$ & $4.1(0.03)$ & $0.5(0.8)$ & $0.5(0.8)$ \\
\hline \multirow{6}{*}{$\begin{array}{l}2014 \text { severity per infected } \\
\text { leaflet (\% area) }\end{array}$} & 5 & $1.08 \mathrm{a}$ & $0.48 \mathrm{a}$ & $1.18 \mathrm{a}$ & $0.58 \mathrm{~b}$ \\
\hline & 7.5 & $0.75 \mathrm{~b}$ & $0.61 \mathrm{a}$ & $0.87 \mathrm{~b}$ & $0.76 \mathrm{ab}$ \\
\hline & 10 & $0.62 \mathrm{~b}$ & $0.60 \mathrm{a}$ & $1.01 \mathrm{ab}$ & $0.52 \mathrm{~b}$ \\
\hline & 12.5 & $0.66 \mathrm{~b}$ & $0.70 \mathrm{a}$ & $0.74 \mathrm{~b}$ & $0.90 \mathrm{a}$ \\
\hline & 15 & $0.58 \mathrm{~b}$ & $0.61 \mathrm{a}$ & $0.81 \mathrm{~b}$ & $0.51 \mathrm{~b}$ \\
\hline & $F$ value $(P)$ & $3.9(0.004)$ & $0.6(0.7)$ & $3.1(0.02)$ & $0.6(0.7)$ \\
\hline \multirow{6}{*}{$\begin{array}{l}2013 \text { severity per fruit } \\
\text { (first fruit sample \% area) }\end{array}$} & 5 & $58.89 \mathrm{a}$ & $3.45 \mathrm{~d}$ & $10.34 \mathrm{a}$ & $2.99 \mathrm{a}$ \\
\hline & 7.5 & $53.19 \mathrm{~b}$ & $7.74 \mathrm{~cd}$ & $3.24 \mathrm{bc}$ & $4.22 \mathrm{a}$ \\
\hline & 10 & $48.50 \mathrm{~b}$ & $13.59 \mathrm{~b}$ & $8.22 \mathrm{ab}$ & $2.34 \mathrm{a}$ \\
\hline & 12.5 & $49.29 \mathrm{~b}$ & $11.98 \mathrm{bc}$ & $2.08 \mathrm{c}$ & $3.20 \mathrm{a}$ \\
\hline & 15 & $43.16 \mathrm{c}$ & $35.06 \mathrm{a}$ & $2.09 \mathrm{c}$ & $3.24 \mathrm{a}$ \\
\hline & $F$ value $(P)$ & $9.7(<0.0001)$ & $36.9(<0.0001)$ & $3.8(0.005)$ & $0.1(1.0)$ \\
\hline \multirow{6}{*}{$\begin{array}{l}2014 \text { severity per fruit } \\
\text { (first fruit sample \% area) }\end{array}$} & 5 & $1.98 \mathrm{a}$ & $0.05 \mathrm{a}$ & $0.94 \mathrm{a}$ & $0.02 \mathrm{a}$ \\
\hline & 7.5 & $1.24 \mathrm{~b}$ & $0.07 \mathrm{a}$ & $0.66 \mathrm{ab}$ & $0.11 \mathrm{a}$ \\
\hline & 10 & $0.75 \mathrm{c}$ & $0.08 \mathrm{a}$ & $0.80 \mathrm{ab}$ & $0.03 \mathrm{a}$ \\
\hline & 12.5 & $0.77 \mathrm{c}$ & $0.33 \mathrm{a}$ & $0.52 \mathrm{~b}$ & $0.21 \mathrm{a}$ \\
\hline & 15 & $0.54 \mathrm{c}$ & $0.19 \mathrm{a}$ & $0.45 \mathrm{~b}$ & $0.39 \mathrm{a}$ \\
\hline & $F$ value $(P)$ & $13.5(<0.0001)$ & $0.6(0.7)$ & $1.7(0.1)$ & $0.9(0.5)$ \\
\hline \multirow{6}{*}{$\begin{array}{l}2013 \text { severity per fruit } \\
\text { (second fruit sample \% area) }\end{array}$} & 5 & $33.36 \mathrm{a}$ & $5.73 \mathrm{~d}$ & $13.18 \mathrm{a}$ & $3.05 \mathrm{a}$ \\
\hline & 7.5 & $28.16 \mathrm{~b}$ & $11.32 \mathrm{c}$ & $13.67 \mathrm{a}$ & $4.02 \mathrm{a}$ \\
\hline & 10 & $22.39 \mathrm{c}$ & $12.10 \mathrm{bc}$ & $11.62 \mathrm{a}$ & $5.10 \mathrm{a}$ \\
\hline & 12.5 & $16.95 \mathrm{~d}$ & $16.14 \mathrm{~b}$ & $7.47 \mathrm{~b}$ & $4.08 \mathrm{a}$ \\
\hline & 15 & $14.15 \mathrm{~d}$ & $22.45 \mathrm{a}$ & $6.81 \mathrm{~b}$ & $5.07 \mathrm{a}$ \\
\hline & $F$ value $(P)$ & $31.6(<0.0001)$ & $18.1(0<0.0001)$ & $4.8(0.0007)$ & $0.4(0.8)$ \\
\hline \multirow{6}{*}{$\begin{array}{l}2014 \text { severity per fruit } \\
\text { (second fruit sample \% area) }\end{array}$} & 5 & $18.78 \mathrm{~b}$ & $0.76 \mathrm{~b}$ & $7.96 \mathrm{~b}$ & $0.24 \mathrm{a}$ \\
\hline & 7.5 & $23.57 \mathrm{a}$ & $1.91 \mathrm{~b}$ & $15.16 \mathrm{a}$ & $0.41 \mathrm{a}$ \\
\hline & 10 & $20.30 \mathrm{~b}$ & $2.24 \mathrm{~b}$ & $3.45 \mathrm{c}$ & $0.67 \mathrm{a}$ \\
\hline & 12.5 & $18.10 \mathrm{bc}$ & $5.45 \mathrm{a}$ & $4.74 \mathrm{c}$ & $0.86 \mathrm{a}$ \\
\hline & 15 & $15.07 \mathrm{c}$ & $8.36 \mathrm{a}$ & $4.12 \mathrm{c}$ & $1.09 \mathrm{a}$ \\
\hline & $F$ value $(P)$ & $7.4(<0.0001)$ & $7.4(<0.0001)$ & $17.8(<0.0001)$ & $0.1(1.0)$ \\
\hline
\end{tabular}

\footnotetext{
${ }^{\mathrm{w}}$ In 2013 the leaf sample was collected on 19 July, and the first and second samples of fruit were collected on 3 September and 9 October, respectively. In 2014 , the leaf sample was collected on 8 July, and the first and second samples of fruit were collected on 18 July and 10 October, respectively.

$\mathrm{x}$ Treatments were a nontreated control, ground-based air-blast applied fungicide (air-blast), aerially applied fungicide (aerial), and a combination of air-blast and aerially (air-blast + aerial) applied fungicide.

y If means within the column have different letters, they are significantly different $(\alpha=0.05)$.

${ }^{\mathrm{z}} P$ value indicates the probability of an $F$ value larger than the calculated value if the null hypothesis (of no height differences) is true.
} 
Relationship between scab severity and height. In both 2013 and 2014 the mean severity of scab on fruit in the canopy of nontreated control trees at the first sample was negatively related to sample height: more severe disease was found lower in the canopy $\left(R^{2}=\right.$ 0.91 and 0.84 , respectively) (Table 4, Fig. 1). Mean scab severity and sample height were also negatively related with the second sample $\left(R^{2}=0.97\right.$ and 0.42 , respectively). When the regression model was significant (and even when it was not), trees receiving the air-blast treatment showed a positive relationship between severity of scab and sample height. In 2013 there was a strong relationship for both the first and second samples $\left(R^{2}=0.76\right.$ and 0.95$)$, but in 2014 , only the second sample had a strong positive relationship $\left(R^{2}=0.91\right)$. For the aerial treatments, there was invariably a trend for a negative relationship between scab severity and sample height, but in 2013, only at the time of the second sample $\left(R^{2}=0.87\right)$, and in 2014 at the time of the first sample $\left(R^{2}=0.80\right)$, were these relationships significant. The air-blast + aerial treatment only showed a positive relationship between scab severity and sample height in 2014 at the time of the second sample $\left(R^{2}=0.99\right)$.

Effect of height and application method on spray deposition. The summary results of the analysis indicating the main effects and interactions of sample height $\times$ card position on spray deposition using an air-blast sprayer or aerial applications are presented for each date, both for cards placed in canopies and for cards suspended from helium-filled balloons (Table 5, Supplementary Table 2).

Spray deposition from the air-blast application to trees on 23 May 2013 was greatest at $5 \mathrm{~m}$ in the outer canopy (24.36\%). At all other heights and card positions, spray deposition was low (1.68 to $7.55 \%$ ) (Table 6). However, on 10 September 2013 on those cards at the inner canopy position, air-blast application resulted in greater spray deposition at $0.00 \mathrm{~m}(43.12 \%)$ and $5.00 \mathrm{~m}(35.33 \%)$ compared to $7.5 \mathrm{~m}$ or higher (1.63 to $9.93 \%$ ), and with the outer canopy position cards, most coverage was at $5 \mathrm{~m}(26.97 \%)$ compared to $15 \mathrm{~m}(2.23 \%)$. With the system of cards suspended from helium-filled balloons, on 10 September 2013 when spray was applied using the air-blast sprayer, most spray was collected on the cards at $5 \mathrm{~m}$, regardless of orientation $(100.00$ and $89.91 \%$ for the lower and upper facing cards, respectively). Spray coverage was progressively less with sample heights for both card orientations (1.59 to $65.98 \%$ ), although spray coverage on the upper cards declined more rapidly compared to the lower-facing cards. Spray deposition was low and variable on all cards in trees receiving the aerial sprays. On 21 May 2013, spray deposition ranged from 0.00 to $2.02 \%$, with no clear trend in relation to the card canopy position. Similarly, on 30 August 2013, spray deposition was low (0.02 to 4.65\%) with no evidence of a trend with height. Even using the system of cards suspended on helium-filled balloons, spray deposition of the aerial application on 30 August 2013 was consistently low, regardless of height or card orientation (0.04 to 5.96\%), although in this case there was significantly more spray deposited on the upper-facing cards at $25 \mathrm{~m}$ (5.96\%) compared to $5 \mathrm{~m}(1.14 \%)$.

Linear regression analysis of spray deposition and sample height showed little effect of height with aerial applications regardless of card position or orientation in trees $\left(R^{2}=0.01\right.$ to 0.34$)$ or when attached to the helium-filled balloon system $\left(R^{2}=0.12\right.$ and 0.19$)$ (Table 6). Using the air-blast sprayer, with the exception of the first experiment on 23 May 2013, there was a consistent significant negative linear relationship between sample height and spray coverage in the trees $\left(R^{2}=\right.$ 0.36 and 0.41 ) and when attached to the helium-filled balloon system $\left(R^{2}=0.88\right.$ and 0.92$)$, regardless of card position or orientation.

\section{Discussion}

The observed relationships between severity of scab and sample location in the canopy make sense in the context of proximity to the fungicide spray source. In the nontreated control trees, severity of scab on fruit at most heights was most often significantly greater compared with severity of at least one or more of the other treatments, and the nature of that difference depended on the specific treatment/ height combination. As observed previously (Bock et al. 2013, 2017a), in the canopy of nontreated control trees there was a decline in severity of scab on fruit with sample height in the canopy, as borne out by the regression analysis (a negative relationship with height). Conversely, in trees receiving the air-blast alone treatment, scab severity was lowest in the lower part of the canopy, and invariably significantly lower compared with the control, and either significantly or numerically more severe in the upper canopy, where severity was no different from the nontreated control. The increase in severity with height in air-blast treated trees was borne out by the regression analysis (a positive relationship with height), also in agreement with observations by Bock et al. $(2013,2017$ a). Aerial alone treatments resulted in more severe scab on fruit at lower sample heights in the canopy compared with higher in the canopy, but scab in the lower canopy ( 5 to $10 \mathrm{~m}$ ) was only significantly more severe than in the air-blast treated trees on one sampling occasion. Throughout the canopy, the severity of scab on fruit in aerially treated trees was significantly or numerically consistently less compared with the control. The regression analysis for severity of scab in aerially treated trees confirmed a negative linear trend with height, although it was not always significant. Bertrand and Brenneman (2001) observed more

Table 4. Linear regression ${ }^{\mathrm{w}}$ analysis of the relationship between scab severity and height in pecan trees of cultivar Schley receiving different fungicide treatment application methods in 2013 and 2014

\begin{tabular}{|c|c|c|c|c|c|c|c|}
\hline Year & Response variable (y) & Treatment & $\boldsymbol{\beta}_{0}(\mathrm{SE})$ & $\boldsymbol{\beta}_{1}(\mathrm{SE})$ & $R^{2 \mathrm{x}}$ & $\mathrm{CV}^{\mathbf{y}}$ & $F$ value $(P \text { value })^{\mathrm{z}}$ \\
\hline \multirow[t]{8}{*}{2013} & \multirow[t]{4}{*}{ First sample mean severity per fruit } & Control & $64.8(2.67)$ & $-1.42(0.25)$ & 0.91 & 3.94 & $31.7(0.01)$ \\
\hline & & Air-blast & $-12.6(9.25)$ & $2.70(0.87)$ & 0.76 & 48.0 & $9.6(0.05)$ \\
\hline & & Aerial & $12.0(4.13)$ & $-0.62(0.39)$ & 0.46 & 53.0 & $2.5(0.2)$ \\
\hline & & Air-blast + aerial & $3.4(1.04)$ & $-0.02(0.10)$ & 0.02 & 24.20 & $0.0(0.8)$ \\
\hline & \multirow[t]{4}{*}{ Second sample mean severity per fruit } & Control & $41.7(2.14)$ & $-1.83(0.20)$ & 0.97 & 6.83 & $82.3(0.003)$ \\
\hline & & Air-blast & $-1.76(2.16)$ & $1.53(0.20)$ & 0.95 & 11.89 & $56.5(0.005)$ \\
\hline & & Aerial & $18.1(1.80)$ & $-0.76(0.17)$ & 0.87 & 12.71 & $20.0(0.02)$ \\
\hline & & Air-blast + aerial & $2.6(0.86)$ & $0.16(0.08)$ & 0.58 & 15.04 & $4.1(0.1)$ \\
\hline \multirow[t]{8}{*}{2014} & \multirow[t]{4}{*}{ First sample mean severity per fruit } & Control & $2.41(0.36)$ & $-0.14(0.03)$ & 0.84 & 25.35 & $15.7(0.03)$ \\
\hline & & Air-blast & $-0.07(0.13)$ & $0.02(0.01)$ & 0.52 & 64.58 & $3.2(0.2)$ \\
\hline & & Aerial & $1.18(0.17)$ & $-0.06(0.02)$ & 0.80 & 20.25 & $12.2(0.04)$ \\
\hline & & Air-blast + aerial & $-0.16(0.12)$ & $0.03(0.01)$ & 0.71 & 62.38 & $7.5(0.07)$ \\
\hline & \multirow{4}{*}{ Second sample mean severity per fruit } & Control & $24.3(3.65)$ & $-0.51(0.34)$ & 0.42 & 14.17 & $2.2(0.2)$ \\
\hline & & Air-blast & $-3.76(1.48)$ & $0.75(0.14)$ & 0.91 & 29.38 & $29.1(0.01)$ \\
\hline & & Aerial & $14.3(6.04)$ & $-0.72(0.57)$ & 0.35 & 63.55 & $1.6(0.3)$ \\
\hline & & Air-blast + aerial & $-0.21(0.03)$ & $0.09(0.003)$ & 0.99 & 3.68 & $806.9(<0.0001)$ \\
\hline
\end{tabular}

\footnotetext{
${ }^{\mathrm{w}}$ Linear regression function, $y=\beta_{0}+\beta_{1} x$, where $\beta_{0}$ is the intercept, $\beta_{1}$ is the slope, $y$ is the predicted severity of scab, and $x$ is the intercept

x $R^{2}=$ coefficient of determination (proportion of variability accounted for by $x$ ).

y $\mathrm{CV}=$ coefficient of variation of the regression, which is a unitless measure of variation, calculated as (mean square error $\div$ mean severity of scab) $\times 100$.

z $F$ distribution value tests goodness of fit for the model. The $P$ value indicates the probability of an $F$ value larger than the calculated value if the null hypothesis (of no height differences) is true.
} 
severe scab at $5.0 \mathrm{~m}$ in aerially treated, mature pecan trees compared with those receiving an air-blast spray in one experiment, but that difference was not significant in a second experiment. In the tall trees in our study, aerial treatments were more efficacious compared with the air-blast treatment only at the highest sampling location in the canopy
(15 m) and only in 2013, although severity was consistently numerically less at this height in 2014 too. It is worth noting again that overall severity was less in 2014, and severity is generally inherently lower in the upper canopy of trees compared with lower in the canopy (this study; Bock et al. 2013, 2017a). At all other heights, the air-blast

\section{$1^{\text {st }}$ assessment}

2013

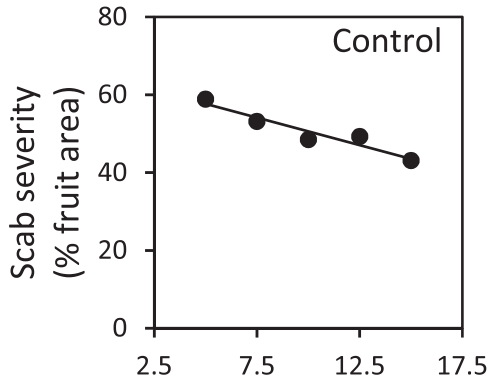

2014

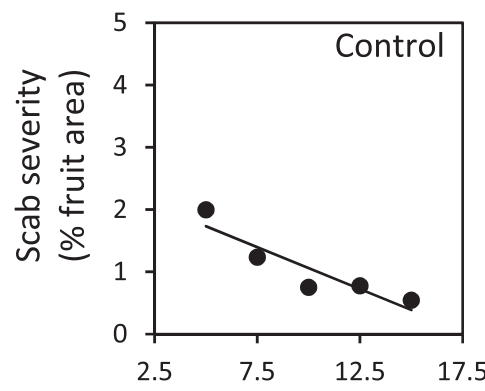

$2^{\text {nd }}$ assessment

\section{3}

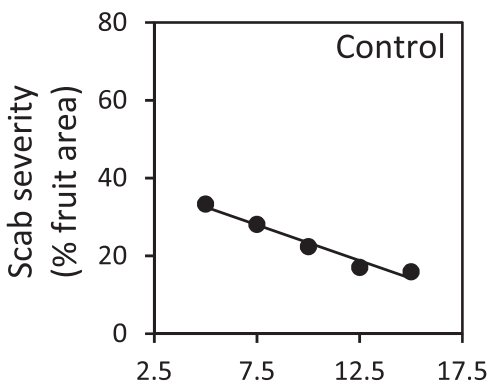

2014

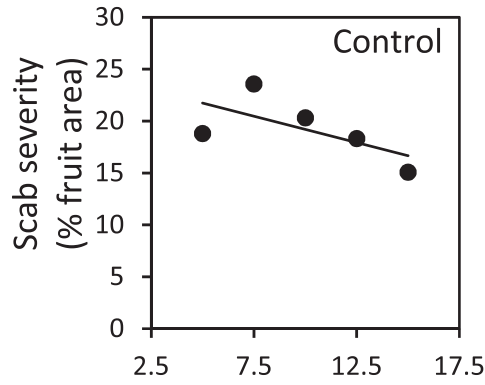

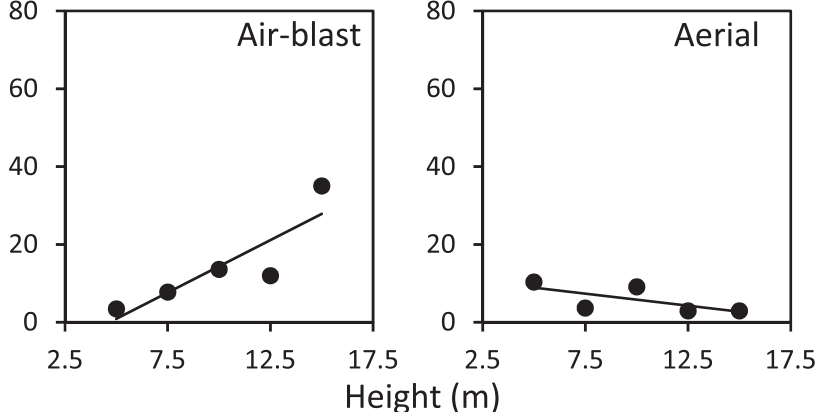

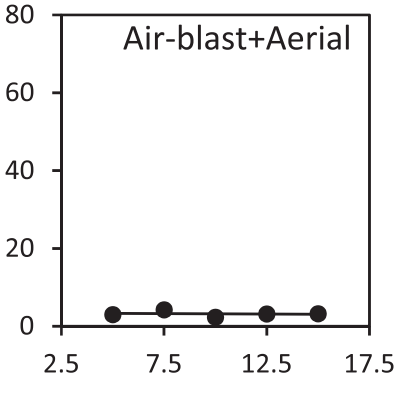

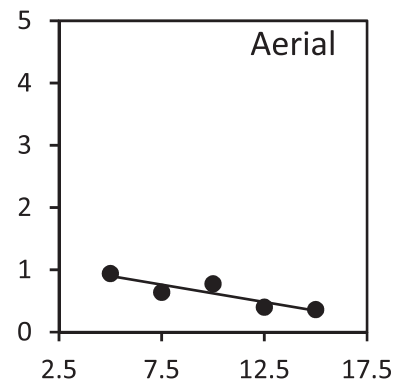

Height $(m)$
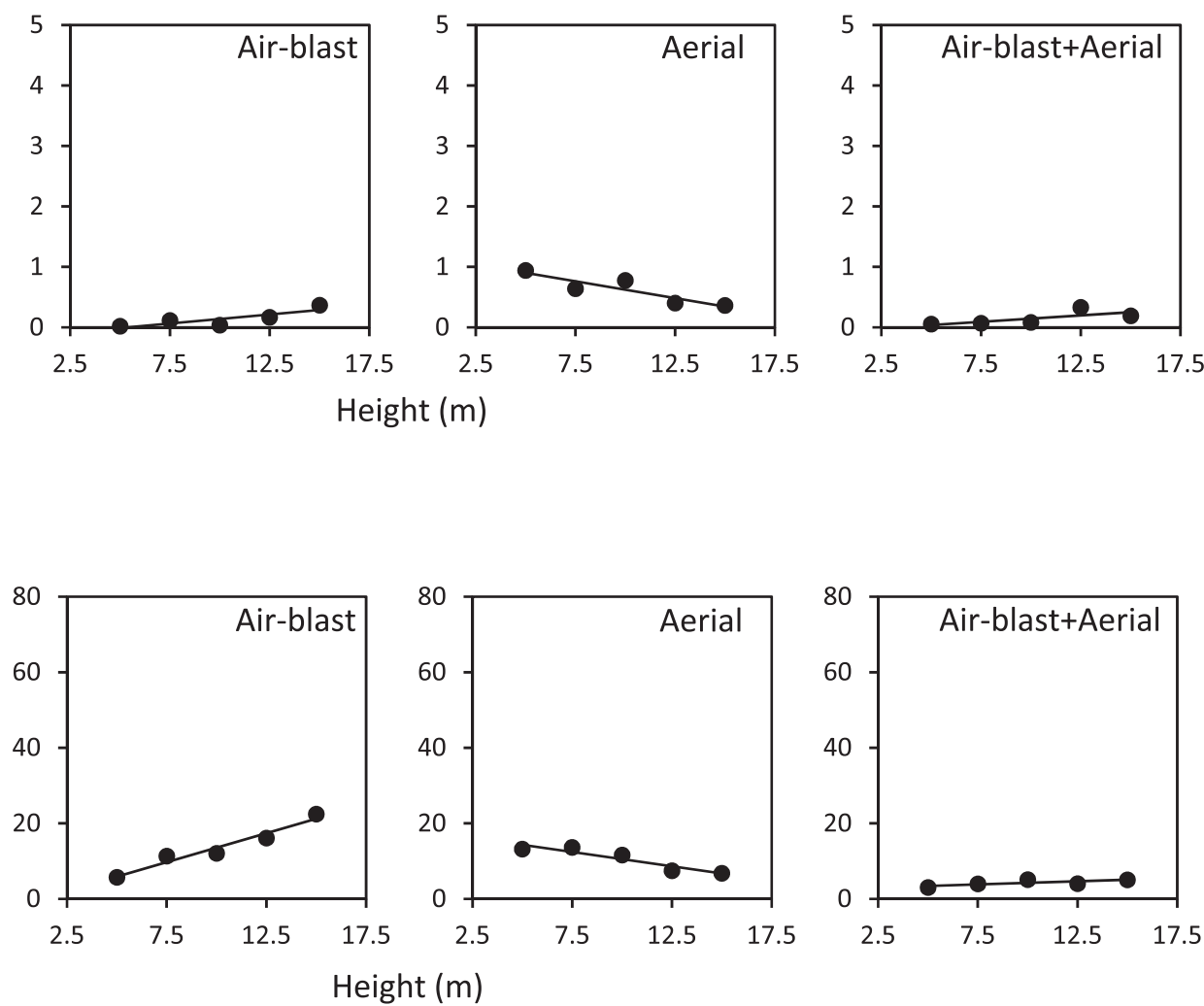

Height $(m)$
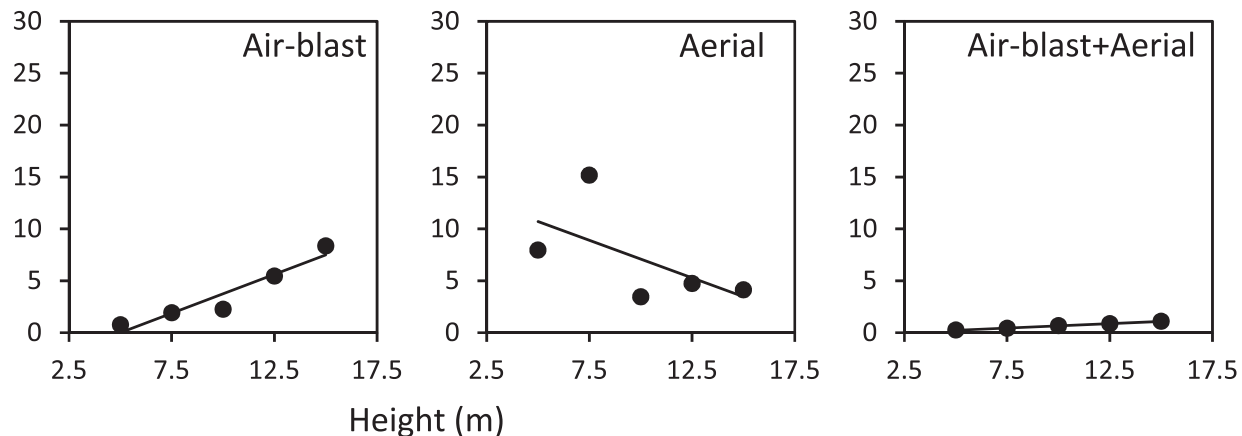

Height $(m)$

Fig. 1. Linear regression of the relationship between mean scab severity on fruit and sample height in pecan trees of cultivar Schley receiving fungicide by different application methods in 2013 and 2014. Observed mean values (circular black markers) and expected values (trend lines) are indicated for each assessment time, year, and treatment method. 
treatments were rarely significantly more efficacious and were most often similarly efficacious as the aerial application (even at 5 and $7.5 \mathrm{~m}$ ). These results indicate that disease control afforded by an equivalent number of similarly timed aerial sprays in 2013 and 2014 rivalled that provided by an air-blast sprayer. This result has some agreement with data presented by Bertrand and Brenneman (2001), although our observations indicate aerial applications to be more efficacious across a wider range of heights in the canopy. The air-blast + aerial treatment consistently resulted in either significantly or numerically the lowest scab severity at all heights. Often the severity was not different from that with the air-blast alone or aerial alone treatments in the lower and upper canopy, respectively (there was little detectable relationship of scab severity for the airblast + aerial treatment with height, and it was only significant for one fruit sample). Thus, the season-long combined treatment resulted in consistently low scab severity at all heights, but whether combined treatment at all sprays would ever be warranted is economically questionable.

In the current study, fruit were sampled twice in each of 2013 and 2014. Epidemics varied between the two years because of weather conditions, as did timing of the sampling. In 2013 the scab epidemic was severe (attaining a maximum mean severity of $50.60 \%$ fruit area diseased on nontreated control trees), whereas in 2014, the epidemic was mild to moderate (maximum mean severity of $19.16 \%$ fruit area diseased on nontreated control trees). Indeed, in 2013 on control trees the epidemic was so severe that fruit drop (personal observation) resulted in a decline in mean severity between September and October. Fruit drop due to scab can be a major contributor to yield loss (Hunter 1983). Despite contrasts in severity between seasons, as noted, the effects of height on severity of pecan scab in relation to treatment method were similar. Timeliness and frequency of sprays are critical factors, as demonstrated by the use of disease advisories to forecast scab risk and spray appropriately (Bertrand and Brenneman 2001; Brenneman et al. 1999; Payne and Smith 2012). In a recent study (Bock et al. 2017a), one to three aerial sprays were applied to different pecan orchards, all of which also received 11 or more ground-based air-blast sprays. Despite the aerial sprays, scab in the upper canopies was relatively severe. In one season (2013, a wet year with major scab epidemics) and location, scab severity on fruit at a height of $17 \mathrm{~m}$ was as high as $77.6 \%$ compared with $3.9 \%$ at $5 \mathrm{~m}$, despite two aerially applied sprays. Nonetheless, scab may have been even more severe had aerial sprays not been applied, although similar patterns occurred at other locations and in other seasons. If only a few aerial sprays are to be applied (one to three), it is recommended that these be timed to coincide with the periods when fruit development is most susceptible to yield loss due to scab-a few weeks after nut set (approximately mid-June) to shell hardening (approximately mid-August) — and applied at times just prior to forecasted major rain events, or even basing the timing on a forecasting system. If the aerial applications can be timed for those events, the more regular, often calendar-based ground-based sprays should ensure adequate disease control on much of the rest of the crop. However, this approach needs to be verified to confirm that only a few sprays thus timed are valuable to maintaining fruit health in the upper canopy.

Generally, effects of fungicide application method on severity of scab on leaves in this study were minimal and often not significant. Mean scab severity was never $>1.18 \%$ area diseased on infected leaflets, although it should be noted that under some conditions foliar scab can be more severe (Latham 1981). However, in most seasons and on most cultivars, scab is rarely severe on leaflets of pecan (Bock and Chiang 2019), so the observations in this study are not unusual, although the lesions on leaflets may be an important source of inoculum. Pecan foliage, unlike fruit, becomes resistant once fully expanded (Gottwald 1985; Turechek and Stevenson 1998); thus, the opportunity for foliage to develop during a window not conducive to disease means that some leaflets or whole leaves can remain scabfree for the entire season, even on susceptible cultivars (Gottwald 1985; Turechek and Stevenson 1998). The low and variable disease severity on leaflets may have precluded seeing clear differences among treatments in both years, although in 2013 and 2014 there was a numeric trend for more severe foliar scab low in the canopy compared with higher in the canopy.

The level of control afforded by the aerial applications is all the more remarkable considering the low volume applied (74 to 94 liters/ha) and the resulting spray coverage when compared with the air-blast sprayer (940 liters/ha). This is especially so in a crop that has such a tall and complex three-dimensional structure as pecan. Previous studies of aerial application in pecan have shown that the quantity of active ingredient on the target is generally equivalent to that provided at the canopy base by an air-blast sprayer, and there is a gradient in active ingredient from the upper to lower canopy (Reilly et al. 2007). However, quantity of active ingredient is not the same as spray coverage or distribution, especially at low volumes. The aerially applied spray basically falls like rain on the canopy. Using water-sensitive cards, we observed relatively poor levels of deposition with the aerially applied sprays, as noted in a previous report (Bock et al. 2015). And with the spray card positions used in this

Table 5. Test of the interaction between canopy height and orientation for fungicide application methods (ground-based air-blast or airplane-applied fungicide sprays) on spray coverage distribution in pecan trees

\begin{tabular}{|c|c|c|c|c|c|c|c|c|}
\hline \multirow{2}{*}{$\begin{array}{l}\text { Application } \\
\text { method }\end{array}$} & \multirow[b]{2}{*}{ Experiment $^{\text {w }}$} & \multirow{2}{*}{$\begin{array}{l}\text { Card position/ } \\
\text { orientation }^{x}\end{array}$} & \multicolumn{6}{|c|}{ Height ${ }^{y}$} \\
\hline & & & 1 & 2 & 3 & 4 & 5 & 6 \\
\hline \multirow[t]{6}{*}{ Air-blast sprays } & \multirow[t]{2}{*}{ Application in trees (23 May 2013) } & Inner & - & $1.82 \mathrm{~b}^{\mathrm{z}}$ & $2.79 \mathrm{~b}$ & $6.99 \mathrm{~b}$ & $4.88 \mathrm{~b}$ & $2.57 \mathrm{~b}$ \\
\hline & & Outer & $1.68 \mathrm{~b}$ & $24.36 \mathrm{a}$ & $3.42 \mathrm{~b}$ & $7.55 \mathrm{~b}$ & $1.71 \mathrm{~b}$ & $4.42 \mathrm{~b}$ \\
\hline & \multirow{2}{*}{$\begin{array}{l}\text { Application in trees (10 September } \\
\text { 2013) }\end{array}$} & Inner & $43.12 \mathrm{a}$ & $35.33 \mathrm{ab}$ & $9.57 \mathrm{~cd}$ & $5.73 \mathrm{~cd}$ & $9.93 \mathrm{~cd}$ & $1.63 \mathrm{~d}$ \\
\hline & & Outer & $15.33 \mathrm{bcd}$ & $26.97 \mathrm{abc}$ & $19.56 \mathrm{bcd}$ & $13.7 \mathrm{~cd}$ & $20.07 \mathrm{bcd}$ & $2.23 \mathrm{~d}$ \\
\hline & \multirow{2}{*}{$\begin{array}{l}\text { Application - helium balloons } \\
\text { (10 September 2013) }\end{array}$} & Upper & $46.16 \mathrm{c}$ & $89.91 \mathrm{a}$ & $65.98 \mathrm{~b}$ & $18.92 \mathrm{de}$ & $3.55 \mathrm{e}$ & $1.59 \mathrm{e}$ \\
\hline & & Lower & - & $100.24 \mathrm{a}$ & $97 \mathrm{a}$ & $50.64 \mathrm{c}$ & $13.55 \mathrm{de}$ & $2.89 \mathrm{e}$ \\
\hline \multirow[t]{6}{*}{ Aerial sprays } & \multirow[t]{2}{*}{ Application in trees (21 May 2013) } & Inner & - & $0.02 \mathrm{~b}$ & $0.02 \mathrm{~b}$ & $0.00 \mathrm{~b}$ & $0.01 \mathrm{~b}$ & $0.17 \mathrm{~b}$ \\
\hline & & Outer & $0.26 \mathrm{~b}$ & $1.16 \mathrm{ab}$ & $1.32 \mathrm{ab}$ & $0.01 \mathrm{~b}$ & $1.99 \mathrm{a}$ & $2.02 \mathrm{a}$ \\
\hline & \multirow[t]{2}{*}{ Application in trees (30 August 2013) } & Inner & $0.11 \mathrm{~b}$ & $0.02 \mathrm{~b}$ & $0.02 \mathrm{~b}$ & $4.65 \mathrm{a}$ & $0.31 \mathrm{~b}$ & $1.12 \mathrm{ab}$ \\
\hline & & Outer & $0.36 \mathrm{ab}$ & $1.69 \mathrm{ab}$ & $1.47 \mathrm{ab}$ & $1.57 \mathrm{ab}$ & $0.36 \mathrm{ab}$ & $0.10 \mathrm{~b}$ \\
\hline & \multirow{2}{*}{$\begin{array}{l}\text { Application - helium balloons } \\
\text { (30 August 2013) }\end{array}$} & Upper & - & $1.14 \mathrm{~b}$ & $1.09 \mathrm{~b}$ & $1.69 \mathrm{ab}$ & $2.35 \mathrm{ab}$ & $5.96 \mathrm{a}$ \\
\hline & & Lower & - & $0.04 \mathrm{~b}$ & $0.14 b$ & $0.24 \mathrm{~b}$ & $1.61 \mathrm{ab}$ & $0.74 \mathrm{~b}$ \\
\hline
\end{tabular}

\footnotetext{
${ }^{\mathrm{w}}$ Water-sensitive spray cards were either placed at different heights in the tree or were attached to platforms at different heights on string suspended by helium filled balloons as indicated.

x In trees, a set of cards was stapled to leaves both on terminals on the inner (close to the trunk) and outer (the canopy surface) canopy of the tree. When attached to platforms suspended from helium-filled balloons, water-sensitive cards were stapled to the upper and lower surface of the platform.

$\mathrm{y}$ For card heights in the tree-based experiments, heights 1,2,3,4,5, and $6=0,5,7.5,10,12.5$, and $15 \mathrm{~m}$, respectively; and for card heights in the helium-filled balloon-based experiments, heights $1,2,3,4,5$, and $6=0,5,10,15,20$, and $25 \mathrm{~m}$, respectively.

${ }^{\mathrm{z}}$ If means within the column have different letters, they are significantly different $(\alpha=0.05)$. "-” indicates no card placed at that position in the experiment.
} 
study there was little indication of a gradient with height in the trees or in the experiment using the helium-filled balloons. The fungicide applied aerially is much higher concentration, but the droplets are spatially less dense when compared with the air-blast sprayer. Thus, the relatively low fungicide coverage (at high concentration) presumably provides sufficient distribution (or redistribution after rewetting events) of fungicide to ensure good protection when applied as frequently as ground-based sprays. Furthermore, the high concentration might withstand effects of weathering (Reynolds et al. 1994). The air-blast sprayer had the highest spray coverage at the lowest height in the canopy (or helium-filled balloon test) in all but one experiment; this distribution has been characterized previously (Bock et al. 2015; Sumner 2004), and our regression analysis bore out these observations. Effects of card positions or orientation, where significant, could be explained by proximity to the spray source and/or shielding from the spray by canopy foliage and branches or presentation of the card.

Both systemic and protectant fungicides were applied using the air-blast and aerial application methods in both seasons and are recommended for management of scab on pecan (Wells 2017). Furthermore, based on information provided by growers, both systemic and protectant fungicides are applied using ground-based air-blast sprayers or by airplane (Bock et al. 2017a). However, considering the low volume applied during aerial application as evidenced in the spray deposition in this study, there may be value in exploring whether the degree of control achieved by a systemic fungicide applied aerially is greater when compared with that using a protectant. A systemic fungicide such as a quinone outside inhibitor or a demethylation inhibitor will have some local internal transfer within the plant tissue, and any fungicide (protectant or systemic) can be redistributed during rain or dew events. Based on the relative ability for internal and external redistribution, there may be advantage to exploring whether either systemics or protectants are more efficacious when applied aerially at low volume. Regardless, managing scab in tall pecan trees will remain a challenge. An alternative is to hedgeprune the trees to reduce height, but even within hedge-pruned orchards there is evidence that a gradient in scab will develop at heights between 10 and $12.5 \mathrm{~m}$ (Bock et al. 2017a).

Previous reports have shown either quantitatively or anecdotally that both aerial and air-blast spray application methods can be efficacious (Bertrand and Brenneman 2001; Bock et al. 2013, 2015; Cole 1951; Cromwell 1972; Graves 1962, 1967, 1968; Graves et al. 1972; Large 1954, 1956, 1961; Wood and Reilly 1999). Likewise, we found the severity of scab was reduced by different amounts at various heights in the canopy dependent on whether fungicide was applied by air-blast or aerially. The air-blast + aerial treatment most often resulted in significantly less severe scab than the nontreated control at all heights. The effects of these fungicide application methods have not been related to the distribution of fruit requiring protection in a canopy. Protection should be selected to provide the greatest efficacy to the largest proportion of fruit in the canopy.

Early-season and season-long sources of asexual inoculum may be affected by fungicide application frequency and the methods used for application. Thus, the in-tree disease distributions we have described when applying air-blast or aerial fungicide will affect the quantity of scab inoculum in the upper and/or lower canopy of tall pecan trees. Overwintering pecan scab lesions on the previous season's nut shucks in the canopy, and on shoots, particularly on tall trees, may be an important source of inoculum early in the season (Demaree 1924). If fungicide management of the tree canopy results in disease developing in the upper canopy, the source of inoculum both early and during the season is a constant threat to the leaves and fruit below as the spores are dispersed in air currents and rain splash (Demaree 1924; Gottwald and Bertrand 1982). Conversely, inoculum may be less when pecan scab is controlled in the upper canopy. In younger, shorter trees, or those that are hedge-pruned to $<12 \mathrm{~m}$, scab will be better-controlled throughout the canopy, and thus inoculum developing due to gradients in control of scab may be less of an issue (Bock et al. 2017a). Finally, the recent discovery of the sexual stage of $V$. effusa (Charlton et al. 2019), and the eventual understanding of its role in the disease cycle in the field, may impact our knowledge of sources of inoculum at different points during the season. Understanding the role of the sexual stage may also provide an opportunity for novel approaches to manage pecan scab.

Further research is needed to explore the relative merits of air-blast versus aerial spray applications, including cost. Clearly both have their advantages (aerial application is faster), and combined they do result in slightly less disease overall at those heights in tall trees where the individual treatments do not provide sufficient coverage (high or low in the canopy). Whether this warrants the combined cost might be questionable. As noted by Bertrand and Brenneman (2001), aerial application may be particularly advantageous in years that are very wet, not only because it is difficult to get on the land using an air-blast sprayer but also because aerial sprays will control disease in the upper canopy that might otherwise be a source of inoculum for susceptible tissue below. Furthermore, the results presented demonstrate that even in trees up to $25 \mathrm{~m}$ tall, aerial sprays applied sufficiently frequently will reduce scab in the lower canopy (but not necessarily to the degree of an air-blast sprayer).

Based on the results of this study there was no outright advantage to applying fungicide by air-blast alone or aerial alone applications (assuming the same number of sprays). The two combined resulted in the lowest disease severity at all heights compared with a trend for increasing or decreasing disease severity with height, respectively.

Table 6. Linear regression ${ }^{\mathrm{w}}$ analysis of the relationship between spray coverage and sample height in pecan trees of cultivar Schley or on platforms attached to helium-filled balloons in 2013

\begin{tabular}{|c|c|c|c|c|c|c|c|c|}
\hline Experiment & Method & Date & Position & $\beta_{0}(\mathrm{SE})$ & $\beta_{1}(\mathbf{S E})$ & $R^{2 \mathrm{x}}$ & $\mathrm{CV}^{\mathbf{y}}$ & $F$ value $(P \text { value })^{z}$ \\
\hline \multirow[t]{8}{*}{ Trees } & Air-blast & 23 May 2013 & Inner & $2.38(4.23)$ & $0.14(0.40)$ & 0.01 & 143.4 & $0.1(0.7)$ \\
\hline & & & Outer & $24.9(9.6)$ & $-1.66(0.91)$ & 0.21 & 149.8 & $3.4(0.09)$ \\
\hline & & & Inner & $39.3(9.5)$ & $-2.68(0.90)$ & 0.41 & 98.9 & $8.9(0.01)$ \\
\hline & & & Outer & $36.1(7.6)$ & $-1.96(0.72)$ & 0.36 & 59.6 & $7.4(0.02)$ \\
\hline & Aerial & 21 May 2013 & Inner & $-0.05(0.05)$ & $0.01(0.005)$ & 0.34 & 130.0 & $5.2(0.05)$ \\
\hline & & & Outer & $0.34(1.02)$ & $0.10(0.10)$ & 0.10 & 83.2 & $1.0(0.4)$ \\
\hline & & 30 August 2013 & Inner & $0.49(2.13)$ & $0.05(0.13)$ & 0.01 & 286.6 & $0.2(0.7)$ \\
\hline & & & Outer & $2.33(1.14)$ & $-0.09(0.07)$ & 0.11 & 180.8 & $1.6(0.2)$ \\
\hline \multirow[t]{4}{*}{ Balloons } & Air-blast & 9 September 2013 & Lower & $164.1(9.7)$ & $-11.1(0.92)$ & 0.92 & 23.7 & $147.8(<0.0001)$ \\
\hline & & & Upper & $131.6(10.6)$ & $-9.6(1.0)$ & 0.88 & 38.0 & $91.5(<0.0001)$ \\
\hline & Aerial & 30 August 2013 & Lower & $-0.31(0.74)$ & $0.06(0.04)$ & 0.12 & 217.9 & $1.7(0.2)$ \\
\hline & & & Upper & $-0.82(2.10)$ & $0.22(0.13)$ & 0.19 & 141.6 & $3.0(0.1)$ \\
\hline
\end{tabular}

\footnotetext{
${ }^{\mathrm{w}}$ Linear regression function, $y=\beta_{0}+\beta_{1} x$, where $\beta_{0}$ is the intercept, $\beta_{1}$ is the slope, $y$ is the predicted spray deposition, and $x$ is the intercept.

${ }^{x} R^{2}=$ coefficient of determination (proportion of variability accounted for by $x$ ).

y $\mathrm{CV}=$ coefficient of variation of the regression, which is a unitless measure of variation, calculated as (mean square error $\div$ mean severity of scab) $\times 100$.

z $F$ distribution value tests goodness of fit for the model. The $P$ value indicates the probability of an $F$ value larger than the calculated value if the null hypothesis (of no height differences) is true.
} 


\section{Acknowledgments}

The authors appreciate the technical expertise and help of Wanda Evans, Minling Zhang, Shirley Anderson, Sue Burrell, Kaylee Carlson, and Jason Shipp at the USDA-ARS-SEFTNRL. We also appreciate the comments and advice on the statistical analysis from Debbie Boykin, USDA-ARS, Stoneville, MS. Also, we thank Frank Bledsoe for aerial applications of fungicide. We also appreciate and acknowledge the senior editor and two anonymous reviewers who made detailed, thoughtful, and constructive comments and suggestions to improve the original manuscript.

\section{Literature Cited}

Bertrand, P. F., and Brenneman, T. B. 2001. Aerial and weather based fungicide application for pecan scab control. Proc. Southeast. Pecan Grow. Assoc. 94:62-69.

Bock, C. H. 2013. Fusicladium effusum. Crop Protection Compendium. CAB International, Wallingford, U.K. https://www.cabi.org/cpc.

Bock, C. H., Brenneman, T. B., Wood, B. W., and Stevenson, K. L. 2017c. Challenges of managing disease in tall orchard trees-Pecan scab, a case study. CAB Rev. 12:1-18.

Bock, C. H., and Chiang, K.-S. 2019. Disease incidence-severity relationships on leaflets, leaves, and fruit in the pecan-Venturia effusa pathosystem. Plant Dis. 103:2865-2876.

Bock, C. H., Cottrell, T. E., Hotchkiss, M. W., and Wood, B. W. 2013. Vertical distribution of scab in large pecan trees. Plant Dis. 97:626-634.

Bock, C. H., Hotchkiss, M. W., Brenneman, T. B., Stevenson, K. L., Goff, W. D., Smith, M. W., Wells, L., and Wood, B. W. 2017a. Severity of scab and its effect on fruit weight in mechanically hedge-pruned and topped pecan trees. Plant Dis. 101:785-793.

Bock, C. H., Hotchkiss, M. W., Cottrell, T. E., and Wood, B. W. 2015. The effect of sample height on spray coverage in mature pecan trees. Plant Dis. 99:916-925.

Bock, C. H., Hotchkiss, M. W., and Wood, B. W. 2017b. Fruit and nut weight in pecan tree canopies in relation to the severity of pecan scab at different heights. For. Pathol. 47:e12331.

Bock, C. H., Hotchkiss, M. W., Young, C. A., Charlton, N. D., Mattupalli, C., Stevenson, K. L., and Wood, B. W. 2017d. Population genetic structure of Venturia effusa, cause of pecan scab, in the southeastern United States. Phytopathology 107:607-619.

Brenneman, T. B., Bertrand, P. F., and Mullinix, B. 1999. Spray advisories for pecan scab: Recent developments in Georgia. Pages 7-14 in: The Pecan Industry: Current Situation and Future Challenges, Third National Pecan Workshop Proceedings. B. E. McCraw, E. H. Dean, and B. W. Wood, eds. USDA Agricultural Research Service, Washington, DC.

Charlton, N. D., Yi, M., Bock, C. H., and Young, C. A. 2019. First description of the sexual stage of Venturia effusa, causal agent of pecan scab. bioRxiv 785790.

Cole, J. R. 1951. Comparative results of applying fungicides with hydraulic and mist sprayers to control pecan scab. Proc. Southeast. Pecan Grow. Assoc. 44:41-48.

Conner, P. J., and Stevenson, K. L. 2004. Pathogenic variation of Cladosporium caryigenum isolates and corresponding differential resistance in pecan. HortScience 39:553-557.

Cromwell, R. P. 1972. Pecan sprayer evaluation. Proc. Southeast. Pecan Grow. Assoc. 65:61-65.

Demaree, J. B. 1924. Pecan scab with special reference to sources of the early spring infections. J. Agric. Res. 28:321-333.

Demaree, J. B., and Cole, J. R. 1929. Behavior of Cladosporium effusum (Wint.) Demaree on some varieties of pecan. J. Agric. Res. 18:363-370.

Goff, W. D., McVay, J. R., and Gazaway, W. S. 1989. Page 222 in: Pecan Production in the Southeast. Alabama Cooperative Extension System Circular ANR-459. Auburn University, Auburn, AL.

Gottwald, T. R. 1985. Influence of temperature, leaf wetness period, leaf age, and spore concentration on infection of pecan leaves by conidia of Cladosporium caryigenum. Phytopathology 75:190-194.

Gottwald, T. R., and Bertrand, P. F. 1982. Patterns of diurnal and seasonal airborne spore concentrations of Fusicladium effusum and its impact on a pecan scab epidemic. Phytopathology 72:330-335.

Gottwald, T. R., and Bertrand, P. F. 1983. Effect of time of inoculation with Cladosporium caryigenum on pecan scab development and nut quality. Phytopathology 73:714-718.
Graves, C. H. 1962. Aerial and mist-blown fungicide application techniques for pecan disease control. Proc. Southeast. Pecan Grow. Assoc. 55:104.

Graves, C. H. 1967. Aerial application of Du-Ter for pecan scab control. Proc. Southeast. Pecan Grow. Assoc. 60:26-30.

Graves, C. H. 1968. Aerial application of fungicides. Proc. Southeast. Pecan Grow. Assoc. 61:145-148.

Graves, C. H., Neel, W. W., and Coats, R. C. 1972. Ultra-low volume (ULV) spray application for pecan disease and insect control. Proc. Southeast. Pecan Grow. Assoc. 65:45-48.

Hunter, R. E. 1983. Influence of scab on late season nut drop of pecans. Plant Dis. 67:806-807.

Lamari, L. 2002. Assess: Image Analysis Software for Plant Disease Quantification. American Phytopathological Society, St. Paul, MN.

Large, J. R. 1954. Summary of two years aeroplane spraying experiments to control pecan scab. Proc. Southeast. Pecan Grow. Assoc. 47:55-67.

Large, J. R. 1956. Aeroplane spraying to control pecan scab in 1955. Proc Southeast. Pecan Grow. Assoc. 49:12-16.

Large, J. R. 1961. Concentrated chemicals applied from a helicopter for the control of pecan diseases. Proc. Southeast. Pecan Grow. Assoc. 54:95-103.

Latham, A. J. 1981. Some factors influencing pecan scab development. Auburn University Agricultural Experiment Station, Auburn University. Highlights of Agricultural Research, Spring 1979 26:7.

Lozano-Gonzalez, R., Storey, J. B., and Harris, M. K. 1992. Three-dimensional characterization of bearing pecan tree. HortScience 27:1181-1183.

Payne, A. F., and Smith, D. L. 2012. Development and evaluation of two pecan scab prediction models. Plant Dis. 96:1358-1364.

Reilly, C. C., Wood, B. W., Cottrell, T. E., Sumner, P., Wells, L., and Funderburk, F. 2007. Comparison of ground and aerial application, fungicide deposition and biological activity in large pecan trees. Proc. Southeast. Pecan Grow. Assoc. 100:115-122.

Reynolds, K. L., Reilly, C. C., Hotchkiss, M. W., and Hendrix, F. F. 1994. Removal of fentin hydroxide from pecan seedlings by simulated rain. Plant Dis. 78:857-861.

Rossman, A. Y., Allen, W. C., and Castlebury, L. A. 2016. New combinations of plant associated fungi resulting from the change to one name for fungi. IMA Fungus 7:1-7.

Sparks, D., Yates, I. E., Bertrand, P. F., and Brenneman, T. B. 2009. The relative impacts of elevation and rainy days on the incidence of scab damage of pecan nuts in the southeastern USA. J. Hortic. Sci. Biotechnol. $84: 137-142$.

Stevenson, K. L. 1999. Fungicide resistance management in pecans. Proc. Southeast. Pecan Grow. Assoc. 92:58-64.

Stevenson, K. L., and Bertrand, P. F. 2001. Within-season dynamics of yield loss due to pecan scab fruit infections. Phytopathology 91:S85.

Stevenson, K. L., Brenneman, T. B., and Brock, J. 2014. Results of the 2014 pecan scab fungicide sensitivity monitoring program. Ga. Pecan Grower Mag. 26:16-23.

Stone, D. 1997. Carya illinoinensis. Flora of North America, Vol. 3. Eds. 1993+. Oxford University Press, Oxford, U.K. http://www.efloras.org/flora_info.aspx? flora_id=1

Sumner, P. E. 2004. Experiences with pecan air blast sprayers. American Society of Agricultural Engineers/Canadian Society of Agricultural Engineers Annual International Meeting, Ottawa, ON, Canada, 1-4 August 2004.

Sumner, P. E. 2012. Pecan orchard air blast sprayers. Cooperative Extension, University of Georgia, College of Agricultural and Environmental Sciences. Bulletin 979. https://secure.caes.uga.edu/extension/publications/files/pdf/B\% 20979_3.PDF

Turechek, W. W., and Stevenson, K. L. 1998. Effects of host resistance, temperature, leaf wetness, and leaf age on infection and lesion development of pecan scab. Phytopathology 88:1294-1301.

Wells, L. 2017. Commercial Pecan Spray Guide. UGA Extension Bulletin 841. University of Georgia, Athens, GA.

Wood, B., and Reilly, C. 1999. Pecan scab disease and its control. Pestic. Outlook 10:12-15.

Yadav, N. V. S., De Vos, S. M., Bock, C. H., and Wood, B. W. 2013. Development and validation of standard area diagrams to aid assessment of pecan scab symptoms on fruit. Plant Pathol. 62:325-335. 